\title{
"Justification of integrated environmental and economic assessment of the impact actions in the field of oil and gas extraction"
}

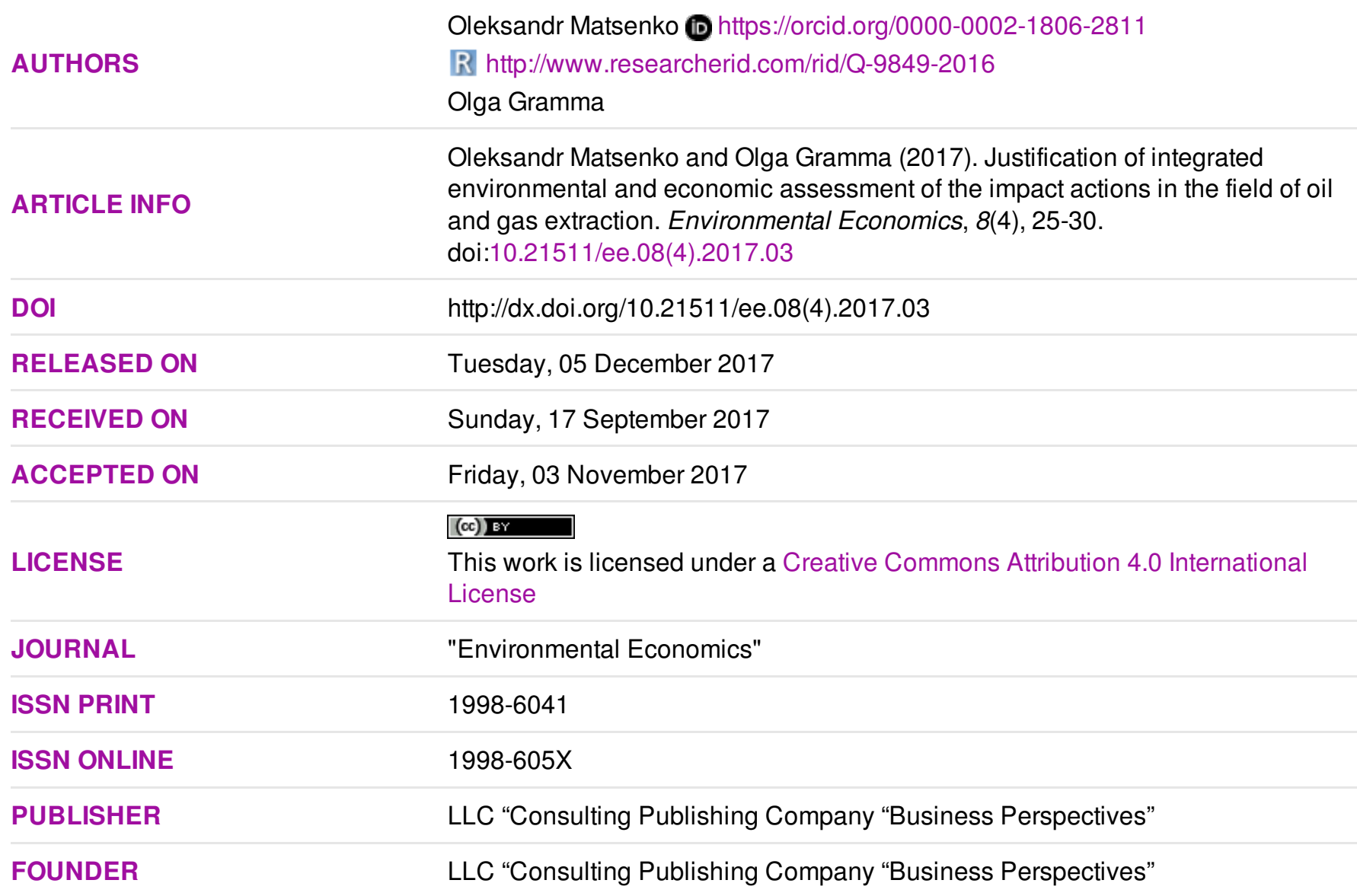

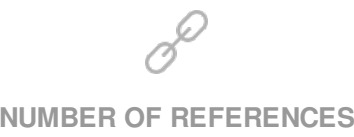

15
NUMBER OF FIGURES

1
NUMBER OF TABLES

1

(C) The author(s) 2022. This publication is an open access article. 


\title{
Oleksandr Matsenko (Ukraine), Olga Gramma (Ukraine) \\ Justification of integrated environmental and economic assessment of the impact actions in the field of oil and gas extraction
}

\begin{abstract}
The aim of the welfare state in accordance with the Constitution of Ukraine is to ensure conditions for the growth of welfare of citizens. One of the major components in the well-being of civilized societies is to ensure that citizens and businesses the necessary energy. Energy development is the basis for enhancing the social and economic living standards of the population and competitiveness. The key to this goal should be a reliable, economically viable and environmentally sound needs of the population and the economy of energy products. It is important to identify the critical factors is a threat to the energy security of the national economy. The state of the energy sector of Ukraine is negatively affected by continued dependence on imports of Russian natural gas, petroleum products and fuel for power plants. Today such dependence on primary energy, including coal, has become a leverage to Ukraine on the part of the neighboring state. The loss of the fuel and energy complex, and areas for future development of hydrocarbon resources as a result of the annexation of the Crimea and the military operations in the east of the country, as well as the destruction of the oil and gas infrastructure in the Donetsk and Luhansk regions, yielded additional new factors which significantly weakened the energy security of the country. Given the instability of strategic task for Ukraine, it is vital to achieve the highest possible level to ensure the economy's own oil and gas resources, which, to a certain extent, will contribute to energy independence and savings of foreign exchange reserves of the country, as well as infrastructure development in the industry, tax revenues, creation of additional jobs.
\end{abstract}

Keywords: oil, oil-producing complex, impact-integrated assessment, ecological and economic damage, environmental loss, environment.

JEL Classification: Q35, Q56.

Received on: $17^{\text {th }}$ of September, 2017.

Accepted on: $3^{\text {rd }}$ of November, 2017.

\section{Introduction}

The activities of the oil industry will inevitably lead to man-made impact on the environment at all stages: field development, industrial production and transportation of hydrocarbons. The impact is made upon almost all components of the environment: air, surface and ground water, soil, minerals, vegetation, biological systems.

The negative impact of industrial activity on the environment has not only a local temporary nature. The long period of impact on natural systems leads to large-scale environmental disasters: changes in tectonic terms of geological environment, water treatment, degradation of biological resources, creation of a greenhouse effect. In the current socio-economic conditions, it is necessary to find and implement economically, socially and environmentally balanced solutions. The approved methods to eliminate pollution of environmental subsystems

(C) Oleksandr Matsenko, Olga Gramma, 2017.

Oleksandr Matsenko, Ph.D., Associate Professor, Associate Professor, Department of Economics and Business Administration, Sumy State University, Ukraine.

Olga Gramma, Researcher, Department of Economics And Business Administration, Sumy State University, Ukraine.

This is an Open Access article, distributed under the terms of the Creative Commons Attribution 4.0 International license, which permits unrestricted re-use, distribution, and reproduction in any medium, provided the original work is properly cited. by oil products do not consider the full cycle of eliminating the risk of secondary pollution and possible extreme and integrated losses in other areas.

\section{Review of recent research sources and publications}

Oil complex market research so far takes one of the central places of interest among international and domestic investors and professionals. Shortage and prices for oil and gas questions remain quite controversial and highly relevant the Ukrainian economy and its socio-economic, technological and environmental safety in general. Many experts from different fields are involved in direct research in this area: economics, technology, ecology, geophysics, hydrogeology, including such scholars as Harrop and Nixon (1999), Morris and Therivel (1995), Saprykin and Bulatov (2004), Keselman (1981). A significant contribution to the theory of damage to the environment and public health from anthropogenic human activities was made by (Balatskyy (1983, 1984, 2007), Danylyshyn, Hvesyk, and Golyan (2010), Telyzhenko (2001), Melnik and Sotnik (2015), Tarkhov (2005) and others. Considering the significant studies of these researchers, it should be noted that despite the lack of domestic energy resources, we need additional study approaches to integrated assessment of economic and environmental losses that can occur during oil operations. 


\section{Basic material and results}

The oil pollution refers to the least studied environmental and economic problems in Ukraine. The negative impact of oil on soil, vegetation, air, surface and ground water, ecosystems in general and health can be noted at all stages of oil operations from drilling and industrial processing to delivery to the consumer and equipment elimination.

One major problem is the lack of information to assess the economic damage and the losses to the environment and the local population by processes of extraction, transportation and processing of oil and its components, as well as the lack of a mechanism of integrated (complex) evaluation of human impacts from oil processes.

At present, the legislation of Ukraine doesn't provide the publication of reports about the human impact on the environment in the oil extraction areas. There aren't also information digests of detailed assessment of environmental and economic damage and description of decision making as to the regional losses minimization during oil and gas projects realization. Currently, Departments of Environment and Natural Resources of Regional State Administration electively publish only a list of documents that govern the assessment of environmental impact and are under consideration and those that received the endorsement of environmental assessment.

The main regulatory document governing the procedure for assessing the impact on the environment or environmental assessment in our country is the Law of Ukraine "Ecological expertise". The list of laws and regulations of Ukraine according to which EIA is developed also includes the Law of Ukraine "On Environmental Protection", "On Air Protection", "On Health care”, Wood, Water and Land Code of Ukraine Resolution of Cabinet of Ministers of Ukraine as to the environment and international Conventions "On Transboundary EIA", "On access to information, public participation in decision making and access to justice issues concerning environment".

International experience with environmental losses assessment procedures is richer than domestic. That's why lots of materials on the subjects are covered in foreign publications and reports on strategic environmental assessment of plans and programs development. Ukraine has a list of subject that have to undergo compulsory environmental assessment. The oil complex belongs to those activities that require compulsory complex ecological and economic assessment (Adamenko, 2005).
Overall, 60 percent of oil complex enterprises are the high-risk facilities. For these companies, more accurate is the assessment of the impact of action, which includes not only the assessment of environmental damage, but also unpredictable events that ultimately lead to economic losses of oil and gas enterprise and of region and state as a whole. The impact operations include oil spills, getting oil compounds related to the production of chemicals into groundwater, noise pollution, unauthorized connections, explosions, etc.

Assessment of the impact of oil complex impact on the environment and human health in areas of oil and gas extraction, it is necessary to consider the whole cycle of oil operations. But as a rule, the extent of environmental negative impact depends on the quality of works on construction of oil industry objects, including drilling, and implementation of industrial processes. In addition, the European experience (Adamenko, 2005) suggests to organize all impact assessments as primary, secondary and integrated. The primary influences are the integrated effects caused directly by the activities in the field and are connected with the construction, maintenance and reconstruction of trading objects. Secondary or indirect are the external effects caused by primary effects and occur in other circumstances of time and place. Integral effect is a synergistic effect which is the result of primary and secondary effects, taking into account their negative impact over time. We studied the effects of negative impact on the environment and human health as a result of the operation of individual deposits in Okhtyrka district of Sumy region where there is the pollution of the fertile soil by oil that causes significant economic losses (Rubanov, 2011).

Gramma and Shkarupa (2016) have made an analysis and systematized the influence of oil and gas impact operations on the environment at the local level separately for the following areas: air, surface, soil, groundwater, social environment (public health). Table 1 shows the characteristics of primary, secondary and integrated regional impacts of natural territorial complex activity on oil production. Except for the composed factors for each subsystem, environmental man-made impacts are marked as types of anthropogenic disturbances and dangerous processes and their characteristics, types of pollution and contaminants. Each element has its own substructure concerning the details of described violations or contamination (see Table 1 in Appendix).

Based on the classified potential consequences of environmental impacts and impact actions of oil production on natural territorial complex, the 
research is directed to formation of integral indicators of anthropogenic influence in areas of extraction equipment pollution.

Impact-integrated assessment of ecological and economic damage to the environment of the region should start from development and exploitation of oil fields (Fig. 1). On the one hand, it is clear phasing of works provided by typical projects, on the other hand, the emergence of balanced related projects that are associated with objects necessary for the operation of the main objects of deposits. But the integrated assessment requires clearly defined legal framework to compensate the negative impact of oil activities set to the region population. In the regulations, the scheme works and presentation of results, including compensation of damages, should be clearly specified.

Impact-integrated evaluation includes, first of all, identification of the most significant sources of risk (risk factors) and their ranking in view of the stability of the system based on mapping risk scenarios of emergencies and determining the stability thresholds of oil complex, usage of mathematical methods - simulation, use of assessment methods and decision-making methods. The first group of indicators should reflect the change in the proportion of destabilizing factors, such as the impact actions from oil spills, associated gas flaring, shock wave, and so on.

The resulting indicators of this group are as follows:

- social - mortality, disability, morbidity;

- environmental - quality deterioration and increasing pressure on the environment;

- economic - loss of national wealth, the additional losses of society.

The second group of indicators reflects a system of measures to minimize the damage. It includes indicators characterizing the ratio of costs that are directed to prevent the impact actions to the total value of the anticipated losses and compensation costs; change in the share of preventive and compensatory costs in total costs on regulation emergencies.

A normative model of the availability and use of natural resources prognosis including impact action is shown in Fig. 1 (see Appendix).

\section{Conclusion and recommendations for further research}

Currently integrated assessment of the extent of oil pollution in Ukraine is absent, only fragmentary assessment of how oil complex influences the individual components of the environment is carried out. Analysis of the problems of oil pollution has shown the appropriate use of impact-integrated methods of ecological and economic evaluation of effects of petroleum on the environment and public health in the fields of direct production and transportation of oil.

Impact-integral method is to determine the integral index of human impact on the environment based on an assessment of impact actions on certain indicators of natural ingredients. The proposed approach provides a more systematic picture of the environmental and economic costs and losses that are connected with oil-producing processes that promote more effective decision-making on development strategies for socio-economic development of areas, study of investment projects on regional, national and international levels, improvement of the quality of life, improvement of hygienic living conditions through the identification of causes of certain diseases types spread, improvement of water supply of settlements that are located in the risk of oil pollution, determination of compensation costs for the parties which bear additional costs of environmental degradation resulting from oil pollution, improvement of the efficiency of allocation of funds from environmental funds of local and state level, as well as making strategic decisions as to the oil and gas projects implementation.

\section{References}

1. Adamenko, Y. O., Kundelska, T. V., \& Nykolyak, M. N. (2005). Impact assessment of development of oil, gas and condensate fields on environmental. Journal of Exploration and development of oil and gas fields, 3(16), 53-58.

2. Balatskyi, O. F, Tarkhov, P. V. \& Rybalov, A. A. (1983). Peculiarities of hygienic recommendations in regional planning based on the prognosis of damage from increased morbidity among the population. Nature protection in conditions of intensive chemicalization of agriculture: theses of reports of the republican scientific and technical conference (Kishinev, December), 13-15.

3. Balatskyy, O. F., Melnik, L. G., Mishenin, E. V., \& Semenenko, B. A. (1984). On some approaches to assessing economic damage from the impact of the Kansk-Achinsk fuel and energy complex on the environment. Current state and projected changes. In L. I. Boltneva, \& I. M. Nazarova (Eds.), The environment under the influence of KATEK: a scientific and technical collection (pp. 201-209). Gidrometeoizdat.

4. Balatskyi, O. F. (2007). Anthology of the economy of a clean environment (p. 272). Sumy: ITD "University Book".

5. Bulatov, V. I. (2004). Oil and Ecology: Scientific priorities in the study of oil and gas complex (p. 155). Novosibirsk: SPSTL RAS, Ugra scientific institute of information technology. 
6. Danylyshyn, B. M., Hvesyk, M. A., \& Golyan, V. A. (2010). Environmental Economics (p. 456). Condor.

7. Gramma, O. M., \& Shkarupa, E. I. (2016). Impact-integrated approach to environmental and economic assessment of damage in the oil extraction places. Journal of Mechanism of economy regulation, 3.

8. Harrop, D. O., \& Nixon, J. A. (1999). Environmental Impact Assessment in Practice (p. 219). London.

9. Keselman, G. S., \& Mahmudbekov, E. A. (1981). Environmental protection during the extraction, transport and storage of oil and gas (p. 256). Moscow: Nedra.

10. Melnik, L. G., \& Sotnik, I. N. (2015). Economics of energy (p. 378). Sumy: University book.

11. Morris, P., \& Therivel, R. (1995). Methods of Environmental Impact Assessment (p. 289). London: UCL Press.

12. Rubanov, P. M., Matsenko, O. M., Gramma, O. M., \& Matsenko, O. I. (2011). Environmental and economic analysis of land and water resources by oil extraction. Efficient economy, 12. Retrieved from http://www.economy.nayka.com.ua/?op=1\&z=875

13. Saprykin, V. (2001). Energy of Ukraine: economic, political and strategic dimension. Retrieved from http://www.razumkov.org.ua/ukr/article.php?news_id=164

14. Tarkhov, P. V. (2005). Criteria of state regulation of the economy. Sumy: Mriya-1.

15. Telizhenko, A. M., Lukyanikhin, V. A., \& Lukyanikhina, E. A. (2001). Assessment of economic damage from pollution of the water basin (p. 68). Sumy: Sumy State University. 
Appendix

Table 1. Impact actions of oil and gas production on the regional natural territorial complex

\begin{tabular}{|c|c|c|c|c|}
\hline $\begin{array}{l}\text { Types of impact } \\
\text { actions }\end{array}$ & $\begin{array}{l}\text { Transforming } \\
\text { components and } \\
\text { processes }\end{array}$ & $\begin{array}{l}\text { Primary effect } \\
\text { (changes) }\end{array}$ & $\begin{array}{l}\text { The secondary impact } \\
\text { (process - consequences) }\end{array}$ & $\begin{array}{c}\text { Integral effect } \\
\text { (consequences for local } \\
\text { development) }\end{array}$ \\
\hline 1 & 2 & 3 & 4 & 5 \\
\hline $\begin{array}{l}\text { Violation of natural } \\
\text { landscapes }\end{array}$ & $\begin{array}{l}\text { complex rocks, } \\
\text { groundwater, soils }\end{array}$ & $\begin{array}{l}\text { Mechanical destruction of the } \\
\text { underlying rocks during drilling, } \\
\text { depression funnels } \\
\text { and fields; regressive fields. } \\
\text { Disintegration of surface soil } \\
\text { masses; changing of thermal } \\
\text { characteristics of the lands and } \\
\text { soils }\end{array}$ & $\begin{array}{l}\text { Redistribution of layer } \\
\text { pressure; overflows of fluids; } \\
\text { Regime change and chemical } \\
\text { part of the deep aquifers; infiltration and } \\
\text { outflow of liquids and gases to the surface, } \\
\text { soil subsidence, landslides, changing the } \\
\text { permeability of the underlying rocks bridges; } \\
\text { Regional surface subsidence, increase of } \\
\text { erosion }\end{array}$ & \multirow[t]{2}{*}{$\begin{array}{l}\text { Reducing the biological } \\
\text { productivity of plant biomass, } \\
\text { reducing species diversity, } \\
\text { changes in water regime } \\
\text { reduction of economic and } \\
\text { recreational value of land and } \\
\text { violation of the aesthetics of } \\
\text { the landscape, increasing the } \\
\text { risk of accidents due to } \\
\text { landslides }\end{array}$} \\
\hline $\begin{array}{l}\text { Chemical pollution } \\
\text { of soil by } \\
\text { hydrocarbons }\end{array}$ & $\begin{array}{l}\text { Relief, processes of } \\
\text { relief creation }\end{array}$ & $\begin{array}{l}\text { Formation of technogenic relief: } \\
\text { positive forms (embankments, } \\
\text { shafts) negative (excavation, } \\
\text { quarries, barns, trenches); } \\
\text { mechanical damage of micro- } \\
\text { and nanorelief output }\end{array}$ & $\begin{array}{l}\text { Flat and linear erosion } \\
\text { (ravines, washouts) trough subsidence, dips, } \\
\text { subsidence, cracks; kriohenez seasonal } \\
\text { change of melting-freezing termoerosions, } \\
\text { soil movements, karst - failures, subsidence, } \\
\text { suffusion; deflation - hollow blowing }\end{array}$ & \\
\hline $\begin{array}{l}\text { Thermal effects in } \\
\text { combustion of oil } \\
\text { and gas (in the fire } \\
\text { lesion places) } \\
\text { The shock wave of } \\
\text { the explosion of } \\
\text { gas or oil vapors, } \\
\text { oil products (in the } \\
\text { affected area) }\end{array}$ & $\begin{array}{l}\text { Biota, } \\
\text { flora and fauna }\end{array}$ & $\begin{array}{l}\text { The construction and (or) partial } \\
\text { destruction of vegetation in the } \\
\text { construction of technical objects } \\
\text { or fire. Violation of landscapes in } \\
\text { places of nesting birds, loss of } \\
\text { conditions of fish fauna }\end{array}$ & $\begin{array}{l}\text { Degradation of vegetation, reduction in species } \\
\text { composition, formation of specific zones of } \\
\text { vegetation along technical facilities; change in } \\
\text { normal growth and activity of aquatic organisms. } \\
\text { These apply meadows, marsh vegetation } \\
\text { formation, appearance halophytic plant groups } \\
\text { (or individual halophytic plants): the appearance } \\
\text { of out of zones "Aliens"; the chemical } \\
\text { composition of plants change - the accumulation } \\
\text { of toxic compounds and elements (including } \\
\text { PAH). Disease and death of } \\
\text { plants, the cause of their morphological changes } \\
\text { - tumor necrosis, chlorosis, and so on, } \\
\text { restructuring of soil biocenoses (species } \\
\text { composition). The destruction of pastures. } \\
\text { Changing the number of birds and mammals, } \\
\text { depletion of species composition and } \\
\text { until number of fish fauna till complete death of fish }\end{array}$ & $\begin{array}{l}\text { The destruction of flora and } \\
\text { fauna, reducing biological } \\
\text { productivity of plant biomass, } \\
\text { reducing species diversity, } \\
\text { changes in water regime, } \\
\text { changing the area } \\
\text { landscapes. } \\
\text { Fatal and severe injuries, } \\
\text { reducing economic and } \\
\text { recreational value of land and } \\
\text { violation of the aesthetics of } \\
\text { the landscape, } \\
\text { risks of technogenic danger }\end{array}$ \\
\hline \multirow[t]{2}{*}{$\begin{array}{l}\text { Chemical water } \\
\text { pollution by } \\
\text { hydrocarbons }\end{array}$} & $\begin{array}{l}\text { Water objects, } \\
\text { hydrological } \\
\text { and hydrochemical } \\
\text { processes }\end{array}$ & $\begin{array}{l}\text { Changing conditions of the } \\
\text { surface, land and groundwater } \\
\text { and wastewater treatment; } \\
\text { changing the speed of the water } \\
\text { masses and water supplies; } \\
\text { mixing of water masses of } \\
\text { different genesis through } \\
\text { groundwater overflows }\end{array}$ & $\begin{array}{l}\text { The rise of groundwater and overdamping of } \\
\text { soils, waterlogging; lowering of groundwater } \\
\text { levels - draining and drying of landscapes, } \\
\text { exhaustion of aquifers; exhaustion of soil } \\
\text { moisture reserves, depletion of sources of } \\
\text { salinity, degradation of wetlands. Changing } \\
\text { the chemical properties of surface and } \\
\text { groundwater (pollution by oil, petroleum, } \\
\text { hydrogen sulfide, water-soluble salts, } \\
\text { reagents for drilling and well testing, } \\
\text { increasing turbidity of water films), changes in } \\
\text { physical, physico-chemical properties of } \\
\text { water, the composition and properties of } \\
\text { sediments - the deterioration of aeration, } \\
\text { hydrogen sulfide contamination, } \\
\text { eutrophication and destruction of water }\end{array}$ & $\begin{array}{l}\text { Reducing of the biological } \\
\text { productivity of water bodies, } \\
\text { reducing of species diversity } \\
\text { The deterioration of drinking } \\
\text { water quality, health } \\
\text { deterioration and systems } \\
\text { and internal organs lesion }\end{array}$ \\
\hline & $\begin{array}{l}\text { Social and economic } \\
\text { conditions and } \\
\text { people's health }\end{array}$ & $\begin{array}{l}\text { The destruction of natural } \\
\text { resources, including industrial } \\
\text { resources of the indigenous } \\
\text { population (hunting, animal } \\
\text { husbandry, fisheries). Changing } \\
\text { of social conditions } \\
\text { (deterioration or improvement of } \\
\text { life comfort) }\end{array}$ & $\begin{array}{l}\text { Limiting opportunities for indigenous people } \\
\text { to engage in traditional activities. Reducing or } \\
\text { increasing of population, changing age and } \\
\text { sex composition. Reducing the availability of } \\
\text { quality water to the population }\end{array}$ & $\begin{array}{l}\text { Changing the infrastructure of } \\
\text { industry, employment and } \\
\text { forms of employment. } \\
\text { Increasing or reducing of } \\
\text { social tensions }\end{array}$ \\
\hline
\end{tabular}

Source: Bulatov (2004) systematized by the author. 
Preliminary analysis of the impact of enterprises on the state of the environment

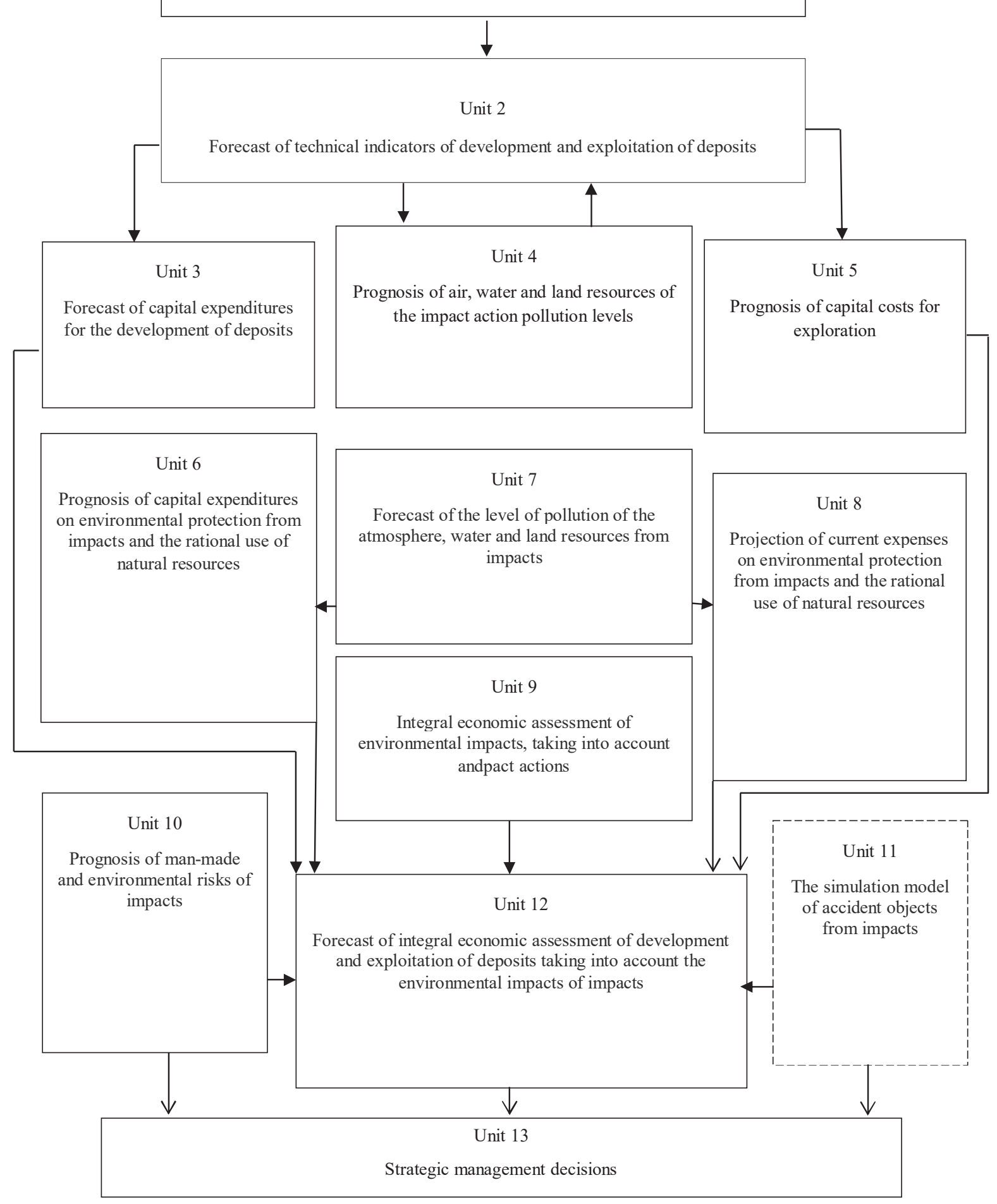

Fig. 1. Impact-integrated assessment of ecological and economic damage to the region environment under development and exploitation of oil fields

Source: Bulatov (2004), systematized by the author. 